\title{
DETERMINANT FACTORS FOR UNDERGRADUATE STUDENT'S DROPOUT IN AN ACCOUNTING STUDIES DEPARTMENT OF A BRAZILIAN PUBLIC UNIVERSITY
}

\author{
SAMUEL DE OLIVEIRA DURSO - (https://orcid.org/0000-0003-0016-3611) * \\ Fundação Instituto de Pesquisas Contábeis, Atuariais e Financeiras, São Paulo - São Paulo, Brazil \\ JACQUELINE VENEROSO ALVES DA CUNHA - (https://orcid.org/0000-0003-2522-3035) * * \\ Federal University of Minas Gerais, Belo Horizonte - Minas Gerais, Brazil
}

\section{FATORES DETERMINANTES DA EVASÃO DOS ESTUDANTES DECIÊNCIAS CONTÁBEIS DE UMA UNIVERSIDADE PÚBLICA BRASILEIRA ${ }^{1}$}

ABSTRACT: The purpose of this article was to identify explanatory factors for undergraduate student's dropout from the Accounting program of a Brazilian public university. The theoretical platform that guided the study was formulated using three evasion models related to higher education. The survey database consisted of socioeconomic and demographic information of 371 students. The research used quantitative and qualitative methodologies to reach the proposed goal. Quantitative data analysis was performed through logistic regression. The model proposed by the study was able to accurately predict $77 \%$ of the cases of dropout/completion from the sample. The qualitative step was based on five semi-structured interviews with those in the sample who dropped out of their studies. The findings of the research have helped understand the phenomenon of undergraduate student dropout from the Accounting program and stresses the importance of rethinking public policies for the retention of talent and, especially, of those students who depend on their work to maintain their studies.

Keywords: Dropout; Accounting; Higher Education.

RESUMO: O objetivo do artigo foi identificar fatores explicativos da evasão do curso de Ciências Contábeis de uma universidade pública brasileira. A plataforma teórica que norteou o estudo foi formulada por três modelos de evasão voltados para o ensino superior. A base de dados da pesquisa foi composta por informações socioeconômicas e demográficas de 371 estudantes. A pesquisa utilizou metodologias quantitativas e qualitativas

\footnotetext{
* Master in Accounting Science from the Federal University of Minas Gerais (UFMG). PhD candidate in Controllership and Accounting at University of São Paulo (USP). Professor of the Professional Master's Degree Program and Course Coordinator at FIPECAFI College. E-mail:<sodurso@gmail.com>.

** $\mathrm{PhD}$ in Accounting Science from USP; Associate Professor in the Accounting Studies Department of UFMG. Leader of "Grupo de Estudos sobre Pesquisas e Educação Contábil” (GEPEC). E-mail: <jvacbr@yahoo.com.br >.
} 
para alcançar o objetivo proposto. A análise quantitativa dos dados foi realizada por meio de regressão logística. O modelo proposto pelo estudo conseguiu prever corretamente $77 \%$ dos casos de evasão/diplomação da amostra. A etapa qualitativa baseou-se em cinco entrevistas semiestruturadas com os evadidos da amostra do estudo. Os achados da pesquisa ajudam a entender o fenômeno da evasão no curso de Ciências Contábeis e destaca a importância de se pensar políticas públicas para a retenção de talentos e, principalmente, dos indivíduos que estudam e trabalham ao mesmo tempo. Palavras chave: Evasão; Ciências Contábeis; Ensino Superior.

\section{INTRODUCTION}

According to Ortiz and Dehon (2013), in the countries of the Organization for Economic Co-operation and Development (OECD), graduates earn, on average, twice as much as those with only elementary education. The completion of upper education is also related to the increase in life expectancy, improvement in personal and professional mobility, increase in social status, increase in the practice of leisure activities, improvement of the children's quality of life, and reduction of the risk of unemployment (NES, EVANS, \& SUGERSTROM, 2009, ORTIZ \& DEHON, 2013).

These and other factors have intensified studies on higher education dropout in recent decades (WALMSLEY, WILSON \& MORGAN, 2010). In Brazil specifically, in 1995, there has been an intensification of studies on undergraduate student dropout, according to the evaluations of Higher Education Institutions (HEI) (BARDAGI, \& HUTZ, 2009). The abandonment of higher education came to be seen as a public policy problem and evasion rates began to figure among the indicators of the resource allocation sheets for the Higher Education Institutions (HEIs) of the federal system (BRAGA, PEIXOTO \& BOGUTCHI, 2003). Since then, several researches on the subject have been developed in the country (BARDAGI, 2007).

However, there is still no consensus in the literature on the causes of dropout in higher education. Nonetheless, several reasons have been pointed out as being able to lead students to not complete graduation. Among the problems most commonly identified in the literature are vocational issues (BARDAGI \& HUTZ, 2005, BARDAGI, LASSANCE, PARADISO \& MENEZES, 2006, BARDAGI, \& HUTZ, 2009), lack of identification with the teaching staff (SILVA, 2005) and cultural inequalities (GISI, 2006, BAGGI, \& LOPES, 2011).

Although there have been several studies on university evasion in the Brazilian context, the studies related to the accounting area are 
still incipient. Even if there are similarities in the issues related to the abandonment of higher education between the different areas of knowledge, it is fundamental to investigate the causes that lead students of Accounting to evade the course before its completion. This is because most of the students also work while attend university, unlike other related areas, such as Economic and Financial Sciences (DURSO, CUNHA, NEVES, \& TEIXEIRA, 2016). This situation may have made Accounting students more likely to have difficulties completing their undergraduate program (FURTADO, \& ALVES, 2012). Studying workers and working students have additional difficulties related to the needs of reconciling academic, professional and personal activities, which makes the evasion process of these individuals even more complex (LOWE, \& GAYLE, 2007, PEREIRA, BERNARDO, D 'ALMEIDA, \& LOUZADA, 2011, FERREIRA, \& MARTINO, 2012).

In addition, the accounting area in Brazil has undergone a series of changes due to convergence to the international accounting standards. Because of that, the profile of the professional accountant underwent significant changes, demanding skills that were not previously required and creating new job opportunities, which can also have an impact on the motivation of the Accounting student in the country which makes the completion of studies more complex (SANTOS, SOBRAL, CORREA, ANTONOVZ \& SANTOS, 2011, TAMER, VIANA, SOARES, \& LIMA, 2013).

Thus, considering the various factors that affect the dropout rates in higher education, the present study aims to answer the following question: what are the determinants of undergraduate student dropout rates in an Accounting Studies Department of a Brazilian Public University? Therefore, the objective of this study is to identify the explanatory factors of such avoidance. To do so, an analysis of the socioeconomic and demographic information of students who completed their university degree and of those who evaded the program at the Federal University of Minas Gerais has been carried out, as well as the interviewing of students who had dropped out of the program.

\section{THEORETICAL REFERENCE}

\subsection{THEORETICAL MODELS ON DROPOUT IN HIGHER EDUCATION}

For Spady (1970, 1971), essays dealing with the process of dropout in higher education up to the date of his study, despite having broad operational definitions and intellectual perspectives, did not use a rigorous interdisciplinary approach. The author then proposed 
a model to explain evasion in higher education, called the Model of the Dropout Process (MDP), based on the suicide theory developed by Ėmile Durkheim. Figure 1 outlines the assumptions of the MDP.

FIGURE 1. Model of the Dropout Process by Spady

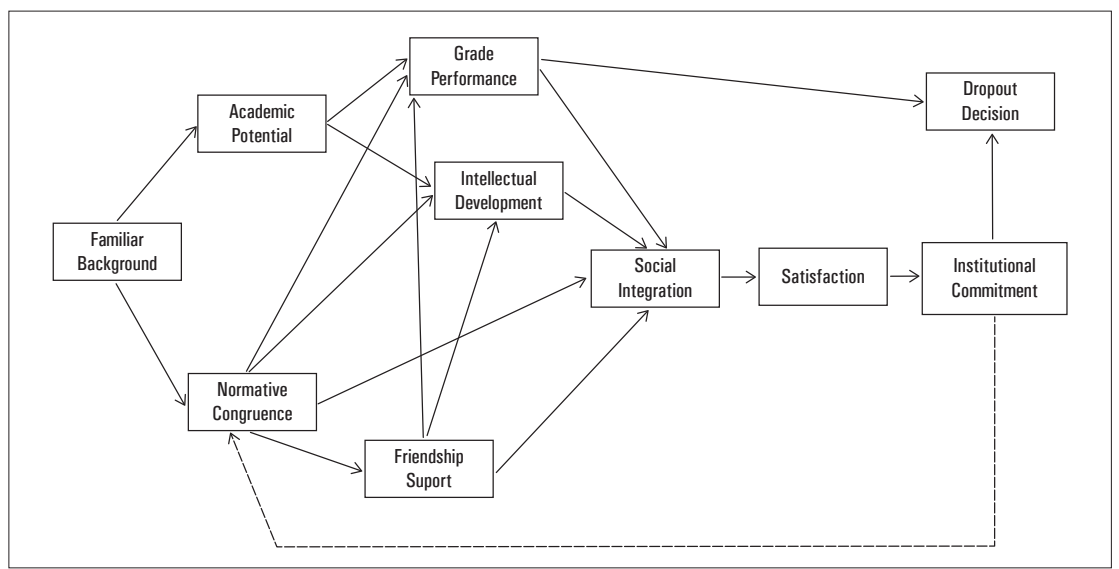

Source: Spady (1970)

For Spady (1970, 1971), dropout in higher education could receive indirect influence from several variables. Among them, the family background that would influence the academic potential of the individual and their normative congruence (understood as the orientation towards the goal of graduation). Academic potential, on the other hand, would influence both the student's intellectual development and their academic performance. Additionally, normative congruence, intellectual development and academic performance, allied to the support of friends, would be able to influence the social integration of the graduate, that is, their identification with the academic environment, including the relationship with the faculty and staff of the institution.

According to the author of the MDP, social integration would be fundamental to determine the level of satisfaction of the graduate related to his higher education, and this satisfaction would influence the commitment of the individual to the institution. Therefore, the lower the commitment to the institution, the greater the student's tendency to drop out of the program.

After Spady's work, several other models were developed based on the variables presented by the MDP. Among the main ones, we have highlighted the Model of Student Integration (MSI) developed by Tinto (1975), which has become widely used in the academic work on the subject (BARDAGI, 2007). For Tinto (1975), 
with the exception of the studies of his predecessor, Spady, research on dropout in higher education presents an inadequate approach to the definition and development of theoretical models that seek to explain, not only describe, the process that culminated in undergraduate dropout in higher education. The MSI, which was also based on Durkheim's theory, is outlined in Figure 2.

One of the main contributions of the MSI relates to the theory of cost and benefit, according to which the individual fails to perform a certain task, such as continuing with studies, for example, when a concurrent activity presents greater benefit for the same level of cost or a lower cost for the same level of benefit. Applied to dropout in upper education, this theory suggests that the university student will drop out when some activity competing with the studies (such as work, in some cases) is more cost-effective than the continuation of studies (TINTO, 1975). Thus, it is expected that the closer to the completion of the undergraduate program, the higher the cost of dropping out compared to the benefit of completing higher education, which would explain the fact that dropout rates are higher in the initial stage of the program as evidenced by several empirical studies (STRAHAM, \& CREDÉ, 2015, WALSH, \& KURPIUS, 2016).

FIGURE 2. Model of Institutional Departure by Tinto

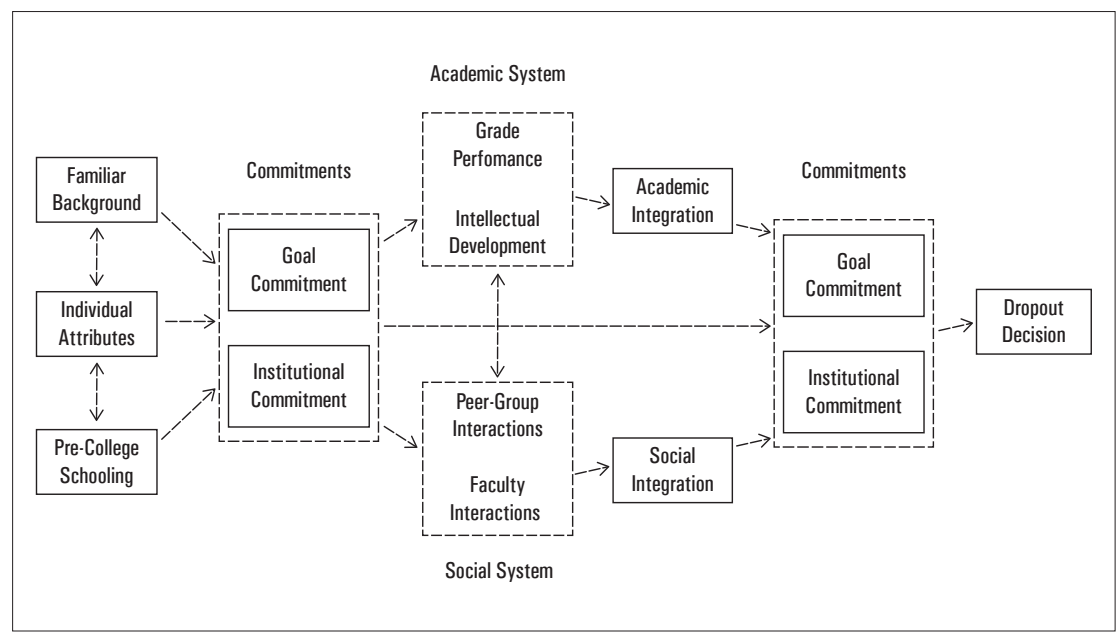

Source: Tinto (1975)

In the following decade after Spady and Tinto's work, a new model was proposed by Bean (1980), called the Model of the Student Attrition (MSA), presented in Figure 3. According to the author of the MSA, the models developed by Spady and Tinto present problems that 
impede more accurate analysis of the research results. The main error would arise from the adaptation of the theory of suicide carried out by the two scholars in the construction of their respective models. In addition, the main studies on dropout in higher education have failed to make clear distinctions between the analytical variables of their models and the demographic variables of higher education students (Bean, 1980). In this context, the MSA proposes an adaptation of the Model of Employee Turnover developed by James Price.

For Bean (1980), the reasons that lead a student to drop out of the undergraduate program would be the same as those that lead a worker to quit. Nevertheless, even pointing out the problems of the models prior to his work, Bean (1980) resorts to some contributions of the study developed by Spady. One of which is to consider the two intervening variables: "satisfaction" and "commitment to the institution" present in the MDP.

FIGURE 3. Model of Student Attrition by Bean

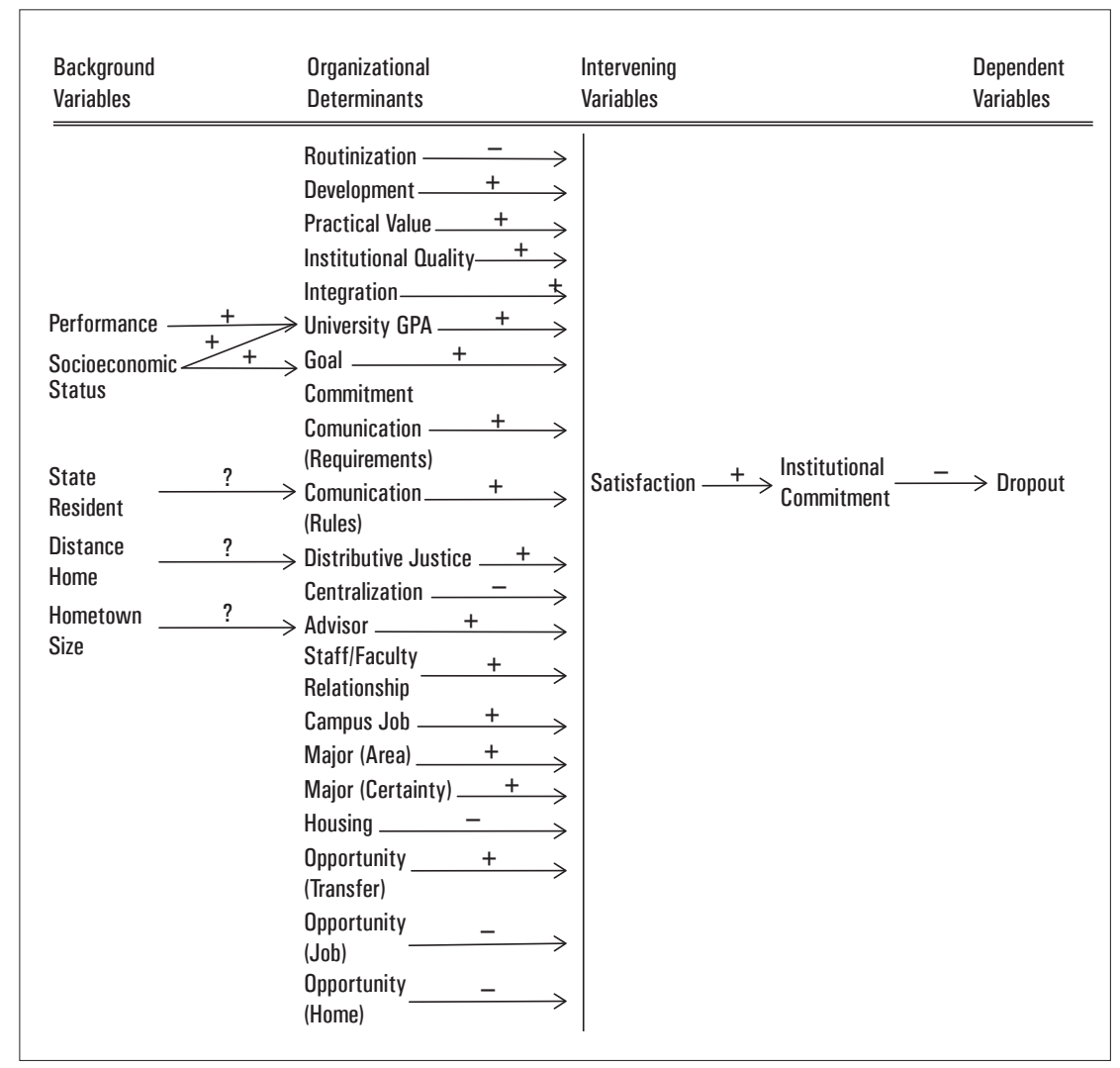

Source: Bean (1980) 
Still from Figure 3, it is possible to see that the MDP considers that both objective variables (such as "performance" and "integration") and subjective variables (such as "practical value") influence students' satisfaction towards the Higher Education System. In addition, as in the MDP, the level of satisfaction directly influences the level of commitment of the student with the HES, which would ultimately determine whether the student will leave the course or complete it. Bean (1980) makes clear, however, that the model developed by him, as well as all those developed in the field of Social Sciences, does not cover all possibilities of occurrence of the problem that he proposes to solve, that is, at no time the author proposes to explain 100\% of the factors that influence the student to drop out of higher education.

\subsection{EMPIRICAL RESEARCH ON EVASION}

Braga, Peixoto and Bogutchi (2003) analyzed the dropout and repetition in Brazilian higher education, using, for that, the case of the Federal University of Minas Gerais (UFMG). The main focus of the analysis was the understanding of the complexity of the relations that are stablished in the campus environment and that can be the cause of the dropout. To do so, the authors used the socioeconomic profile and performance of the students of the previously mentioned institution in programs related to the areas of Health, Social Sciences and Humanities. Data were analyzed using descriptive techniques. Among the main findings, the research suggests that the socioeconomic profile, although important for the student's admission to higher education, has little influence on dropout rates. In addition, the authors identified that the programs analyzed in the area of Humanities (which did not include Accounting), present higher dropout rates than programs in the Health area and lower than those in the area of Social Sciences.

Bardagi (2007) interviewed eight Brazilian students (five men and three women) from different undergraduate programs, in order to identify the reasons that led them to drop out of the program. All of them indicated the vocation, that is, the realization of having applied for a program they showed no interest or aptitude for. In addition, the results found by the author revealed that the emphasis of the answers was on the perceptions of the student's own performance, on the importance of interpersonal relationships, on preferred courses or activities, and on the relationship between the completion of high school and its influence in the choice of a profession. 
Reisel and Brekke (2010) compared the patterns of student attrition among students who belonged to minorities with the attrition patterns of mainstream students. The comparison was made with the United States of America (USA) and with Norway. In the US, the authors considered Afro-descendant and Latin American students as belonging to the minority class, while in Norway they were considered non-Western immigrants. As a main research result, the authors found evidence that in the US the system of higher education tends to accentuate socioeconomic differences between the two groups due to the fact that the risk of evasion is higher in the first group, while in Norway the system does not tend to exacerbate these differences.

Walmsley, Wilson, and Morgan (2010) conducted focus groups with 327 students from an American university attending the first year of undergraduate education and who declared themselves prone to drop out. The objective was to identify the factors that could influence their permanence. The results indicated that among the factors capable of influencing the permanence, family and friends, faculty (proximity to faculty inside and outside the classroom), and extracurricular experiences such as trainee, research and exchange programs.

Cunha et al. (2015) sought evidence on the behavior of dropout and permanence in the context of the study programs of Accounting and Administration of Brazilian Higher Education System. The survey covered the period from 2001 to 2010. The evasion rates by academic organization form the HES were tested through correspondence analysis and analysis of variance. Among the results of the research, it was evidenced that the evasion rate of the Administration program is higher than that of the Accounting studies program. According to the authors, the Accounting studies program presents less evasion in colleges and universities, and the Administration program presents higher dropout rates in colleges, schools, institutes and technological education centers.

Cotton, Nash, and Kneale (2017) examined the evasion process of students considered to be nontraditional in the context of the United Kingdom. Based on the perspective of resilience, the authors analyzed the case of two existing university projects in that country, identifying risks and protective factors for the retention/ evasion phenomena of these students. Data collection included the application of online questionnaires, survey of academic records and interviews. Among the main findings, the article highlights as factors that promote retention: good relationship with faculty and staff, financial support, relationship with friends and family, and extracurricular activities. 


\section{METHODOLOGY}

The present study is classified as descriptive and explanatory. It was carried out from an analysis of secondary data and through semi-structured interviews, thus presenting a quantitate-qualitative approach (Smith, 2003).

Secondary data used by this research were provided by the UFMG's Vestibular Standing Committee (COPEVE), after approval of the project by the Research Ethics Committee (CEP) of this educational institution (Certificate of Presentation for Ethical Assessment $\mathrm{n}^{\circ}$ 31175214.9.0000.5149). This database contains socioeconomic and demographic information of the students who entered the Accounting Studies Program of UFMG between 2004 $/ 1^{\text {st }}$ term and $2009 / 1^{\text {st }}$ term, thus comprising eleven classes (term entries). This information was provided by the individuals themselves when the vestibular was performed by the institution hereby analyzed.

\subsection{QUANTITATIVE STAGE}

The database for model estimation presents information from a set of 371 students (265 graduates and 106 dropouts). From this information, a logistic regression was estimated using Stata12 software. The objective of this methodology was to identify the socioeconomic and demographic variables that influence the students' dropout of the Accounting studies program. The econometric method adopted is a multivariate analysis technique, appropriate for situations in which the dependent variable is binary (FAVERO, BELFIORE, SILVA, \& CHAN, 2009), such as the dropout/completion data.

The value of "1" (one) was attributed to the students who entered the Accounting studies program in between 2004/ $1^{\text {st }}$ term and $2009 / 1^{\text {st }}$ term and dropped out of the program afterwards, and the value " 0 " (zero) to the students that completed their studies. The concept of dropout in the present research is related to the loss of bond with the UFMG's Accounting studies program. This is an institutional approach, from the point of view of Tinto (1975).

Following the validation guidelines of Hair Junior, Black, Babin and Anderson (1998), the study sample was segregated into two subsamples, one called "training", containing $60 \%$ of the total data (222 cases analyzed: 63 of dropouts and 159 of completion), and another called "validation", with the remaining 40\% (149 cases analyzed: 43 of dropouts and 106 of completion).

Figure 4 presents the variables that were created from the information present in the database provided by UFMG and that 
were used to estimate the prediction model of dropout. In addition, the treatment criteria for each of the variables, the research that bases its use on the model, and the expected coefficient for the estimation of the model, considering the evidence in the literature, are also presented in Figure 4.

FIGURE 4. Variables of the Model of Estimated Dropout

\begin{tabular}{|c|c|c|c|c|}
\hline Variable & Name & Attributed Value & $\begin{array}{l}\text { Theoretical } \\
\text { Starting Ground }\end{array}$ & $\begin{array}{l}\text { Expected } \\
\text { Coeficient }\end{array}$ \\
\hline Gender & Sexo & $\begin{array}{l}1 \text { for male students } \\
\text { and } 0 \text { for female }\end{array}$ & $\begin{array}{l}\text { Braga, Peixoto, } \\
\& \text { Bergutchi (2003) } \\
\text { and Matos, \& } \\
\text { Machado (2006) }\end{array}$ & + \\
\hline Age & Idade & $\begin{array}{l}1 \text { for } 19 y 0 \text { or more } \\
\text { when entering the } \\
\text { first term and } 0 \text { for } \\
\text { those under } 19 \text { yo }\end{array}$ & $\begin{array}{l}\text { Lassibille \& } \\
\text { Gomez (2008), } \\
\text { Silva (2013) }\end{array}$ & + \\
\hline $\begin{array}{l}\text { Level of } \\
\text { Parental } \\
\text { Education }\end{array}$ & EscolaridadePai & $\begin{array}{l}1 \text { for students whose } \\
\text { parents hadn't } \\
\text { completed a higher } \\
\text { education program and } \\
0 \text { for those whose } \\
\text { parents had at least } \\
\text { a Bachelor's degree }\end{array}$ & $\begin{array}{l}\text { Schultz (1988), } \\
\text { Reis, \& } \\
\text { Ramos (2011) }\end{array}$ & + \\
\hline $\begin{array}{l}\text { High School } \\
\text { shift }\end{array}$ & TurnoEM & $\begin{array}{l}1 \text { for students who } \\
\text { completed their high } \\
\text { school studies in the } \\
\text { night shift and } 0 \text { for } \\
\text { the ones who studied } \\
\text { during the day-shift }\end{array}$ & $\begin{array}{l}\text { Spady } \\
\text { (1970, 1971), } \\
\text { Tinto (1975) }\end{array}$ & + \\
\hline $\begin{array}{l}\text { Prep Course for } \\
\text { the Vestibular } \\
\text { (SAT test) }\end{array}$ & PreVest & $\begin{array}{l}1 \text { for students who could } \\
\text { afford to pay for a Prep } \\
\text { Course before their test } \\
\text { application and } 0 \text { for } \\
\text { those who could not }\end{array}$ & $\begin{array}{l}\text { Spady } \\
\text { (1970, 1971), } \\
\text { Tinto (1975), } \\
\text { Bean (1980) }\end{array}$ & - \\
\hline $\begin{array}{l}\text { Reading } \\
\text { a Second } \\
\text { Language }\end{array}$ & LeituraLE & $\begin{array}{l}1 \text { for students who } \\
\text { could at least understand } \\
\text { a written second } \\
\text { language and } 0 \text { for } \\
\text { those who admitted } \\
\text { not having that ability }\end{array}$ & $\begin{array}{l}\text { Spady } \\
(1970,1971)\end{array}$ & + \\
\hline
\end{tabular}




\begin{tabular}{|l|l|l|l|l|}
\hline \multirow{3}{*}{ Hometown } & \multirow{2}{*}{ OndeNasceu } & $\begin{array}{l}1 \text { for those who were } \\
\text { born in the city where } \\
\text { the university was } \\
\text { located and O for those } \\
\text { who were born in } \\
\text { a different city }\end{array}$ & $\begin{array}{l}\text { Spady } \\
(1970,1971), \\
\text { Tinto (1975) }\end{array}$ & + \\
\hline Housing & $\begin{array}{l}1 \text { for those who lived } \\
\text { in a house owned } \\
\text { by themselves or } \\
\text { their family and 0 } \\
\text { for those who did not }\end{array}$ & $\begin{array}{l}\text { Tinto (1975), } \\
\text { Gisi (2006), } \\
\text { Baggi \& } \\
\text { Lopes (2011) }\end{array}$ & + \\
\hline
\end{tabular}

In the present study, because the research problem has a strong social character, the level of significance of up to $10 \%$ was acceptable. Different from exact sciences, research related to the social sciences requires greater flexibility in acceptability criteria of statistical significance, being common the acceptability of a significance level that reaches up to $10 \%$ in this area of study (LOUREIRO, \& GAMEIRO, 2011).

\subsection{QUALITATIVE STAGE}

Of 106 dropouts identified in the original research database, 5 accepted to participate in a semi-structured interview (approximately $5 \%$ of the total). Figure 5 shows the characteristics of the dropouts interviewed by the study. One of the interviews was conducted in person, three of them were via Skype and one was by telephone. All the interviews were recorded and transcribed with the permission of the interviewees. All the interviewees signed an Informed Consent Form prior to the interview, in compliance with the determination of the CEP of UFMG. The interviews were conducted during the month of March, 2015.

FIGURE 5. Descriptive Analysis of the Interviewed Students

\begin{tabular}{|c|c|c|c|c|c|c|c|}
\hline Dropout & Gender & $\begin{array}{c}\text { Interview } \\
\text { Date }\end{array}$ & $\begin{array}{c}\text { Interview } \\
\text { Media }\end{array}$ & $\begin{array}{c}\text { Current } \\
\text { Age }\end{array}$ & Residence & $\begin{array}{c}\text { Admission } \\
\text { Date }\end{array}$ & $\begin{array}{c}\text { Dropout } \\
\text { Date }\end{array}$ \\
\hline E & Male & 26 Mar 2015 & Skype & 41 & $\begin{array}{c}\text { with wife } \\
\text { and kids }\end{array}$ & $2008 / 1$ & $2009 / 2$ \\
\hline I & Male & 24 Mar 2015 & On-site & 31 & with wife & $2008 / 2$ & $2012 / 2$ \\
\hline M & Male & 24 Mar 2015 & Skype & 30 & $\begin{array}{c}\text { with } \\
\text { parents }\end{array}$ & $2007 / 2$ & $2009 / 1$ \\
\hline P & Male & 28 Mar 2015 & Telephone & 30 & $\begin{array}{c}\text { with a } \\
\text { roomate }\end{array}$ & $2006 / 2$ & $2013 / 2$ \\
\hline & Female & 25 Mar 2015 & Skype & 27 & $\begin{array}{c}\text { with } \\
\text { parentes } \\
\text { and kids }\end{array}$ & $2006 / 1$ & $2010 / 2$ \\
\hline
\end{tabular}


The script of semi-structured interviews was adapted from Bardagi's (2007) research on dropout in higher education. The pretest carried out with the final script of the interview did not identify the need for any adjustment. The instrument presents three macrocontexts. The first deals with the factors related to the choice of the undergraduate program in Accounting Studies, that is, to the period prior to joining higher education. The second deals with the situations lived by the dropouts in the university environment, that is, in the post-admission period after entering the Accounting Studies program, situations that generated the decision for the dropout. The last macro-context covered by the data collection instrument refers to the current situation of the dropouts and the possible interventions that would have avoided the dropout process.

\section{RESULT}

\subsection{QUANTITATIVE STAGE ANALYSIS}

The objective of this study was to identify explanatory factors for the dropout rate of the Accounting Sciences program of a Brazilian public university. To do so, initially, a model of dropout prediction was drafted through logistic regression formed by eight variables, which are theoretically based in the Accounting literature. For the estimation of the model, the data collected from 159 completions and 63 dropouts of the Accounting Studies program of the UFMG ("training" subsample) was used. In addition, to confirm the predictive power of the model created, a sample consisting of 106 completions and 43 dropouts ("validation" subsample) was used. It should be emphasized that the subsamples "training" and "validation" present data from different individuals. Table 1 shows the result found for the estimation of the model. As it can be seen, all the variables used were statistically significant at the levels of $10 \%, 5 \%$ or $1 \%$.

The variable "Sexo", significant at the level of 5\%, presented a positive coefficient and odds ratio higher than 1 . It can be stated, therefore, that the male subjects of the "training" subsample have a chance factor of dropout equals to 2.1967 times than those of the female gender. This result ratifies what had already been evidenced by surveys that have identified that dropout rates are higher for men (BRAGA, PEIXOTO, \& BERGUTCHI, 2003) and confirms studies that show that women tend to be more educated (MATOS \& MACHADO, 2006).

The variable "Idade", significant at $1 \%$, presented a positive coefficient and odds ratio greater than 1 . It was possible to conclude, therefore, that students entering the Accounting Studies program at 
the age of $19 y 0$ or more present a chance factor related to drop equals to 6.9441 times than their peers who entered the course under the age of 19yo. This result may show that students who enter older have a greater insertion in the market, which makes it difficult to complete their higher education, since there are multiple tasks competing with the academic studies, corroborating with the evidence in the literature (LASSIBILLE \& GOMEZ, 2008; SILVA, 2013) and with models of dropout in higher education (SPADY, 1970; RED, 1975; BEAN, 1980).

The variable "EscolaridadePai", significant at 5\%, presented an opposite result from what was expected. For the context of the subsample "training", it can be said that students whose parents have an educational level lower than Bachelor have a chance factor of dropout equals to 0.4343 times the chance factor of the children whose parents had at least a Bachelor's degree. It was hoped that children of more educated parents would present a family environment more prone to graduation completion (Schultz, 1988, Reis, \& Ramos, 2011).

TABLE 1. Results of the model estimate of dropout prediction

\begin{tabular}{|c|c|c|c|}
\hline Variable & Coefficient & Odds Ratio & Wald's Test \\
\hline Constante & $\begin{array}{l}-1,7942 \\
(0,5443)\end{array}$ & $\begin{array}{c}0,1663 \\
(0,0905)\end{array}$ & $0,001 * *$ \\
\hline Gênero & $\begin{array}{l}0,7870 \\
(0,3711)\end{array}$ & $\begin{array}{c}2,1967 \\
(0,8152)\end{array}$ & $0,034^{* *}$ \\
\hline Idade & $\begin{array}{c}1,9379 \\
(0,5226)\end{array}$ & $\begin{array}{c}6,9441 \\
(3,6292)\end{array}$ & $0,000 * * *$ \\
\hline EscolaridadePai & $\begin{array}{l}-0,8340 \\
(0,3624)\end{array}$ & $\begin{array}{c}0,4343 \\
(0,1574)\end{array}$ & 0,021 ** \\
\hline TurnoEM & $\begin{array}{l}-1,3208 \\
(0,7970)\end{array}$ & $\begin{array}{c}0,2669 \\
(0,2127)\end{array}$ & $0,097^{*}$ \\
\hline LeituraLE & $\begin{array}{l}-1,1591 \\
(0,5634)\end{array}$ & $\begin{array}{c}0,3138 \\
(0,1768)\end{array}$ & $0,040 * *$ \\
\hline PreVest & $\begin{array}{c}-0,7126 \\
(0,3760)\end{array}$ & $\begin{array}{c}0,4904 \\
(0,1844)\end{array}$ & $0,058^{*}$ \\
\hline OndeNasceu & $\begin{array}{c}-0,8413 \\
(0,4152)\end{array}$ & $\begin{array}{l}0,4312 \\
(0,179)\end{array}$ & $0,043^{* *}$ \\
\hline TipoResidência & $\begin{array}{c}0,9999 \\
(0,4278)\end{array}$ & $\begin{array}{c}2,7181 \\
(1,1628)\end{array}$ & $0,019 * *$ \\
\hline Número de Obs. & 222 & & \\
\hline Prob $>\mathrm{Chi}^{2}$ & 0,0000 & & \\
\hline Pseudo $\mathrm{R}^{2}$ & 0,2073 & & \\
\hline${ }^{*}$ Significant at $10 \%$; & Significant at $5 \%$; & at $1 \%$ & \\
\hline
\end{tabular}


The "TurnoEM" variable, significant at the level of $10 \%$, showed a negative coefficient and, consequently, an odds ratio of less than 1. It can be stated, therefore, that most of the students in the sample who attended high school during the night shift have an odds ratio of dropout equals to 0.2666 times the odds ratio of the students who studied the last years of high school in the daytime period. This result is also the opposite of what was expected. It was expected that the students who attended high school during the nightshift would have greater insertion in the labor market, which tends to increase the propensity to dropout as it reduces the commitment to the institution (Red, 1975) and/or normative congruence (Spady, 1970, 1971).

The variable "LeituraLE" also had a negative coefficient and was significant at the level of $5 \%$. From Table 1, it can be stated that students who cannot read in any foreign language have a chance factor of dropout equals to 0.3138 times the chance factor of students who read at least in one foreign language. This result is contrary to expectations. The variable "LeituraLE" was used as a proxy for students' academic potential, and, in view of the Spady's model $(1970,1971)$, individuals with higher academic potential were expected to be less likely to dropout.

The variable "PreVest", on the other hand, presented statistical significance at the level of $10 \%$ and a negative coefficient, as expected by the literature review. It was possible to infer, therefore, that the students of the study sample who attended a prep course before applying for the university entrance examination had a chance factor of dropout equals to 0.4904 times the odds factor of the students who did not attend those courses. In carrying out a prep course for the admission test, there is an increase in the knowledge of the individual, contributing to the higher propensity to complete higher education, according to the literature (SPADY, 1970, 1971, RED, 1975, BEAN, 1980).

The "OndeNasceu" variable, significant at the level of 5\%, contrary to expectations, had a negative coefficient. Thus, it can be stated that, for the context of the "training" sub-sample, the student born outside the city of Belo Horizonte presents a chance factor of dropout equals to 0.4312 times the chance factor of the students who were born in the capital of Minas Gerais. Students from Belo Horizonte were expected to show greater social integration and, according to the models of Spady $(1970,1971)$ and Tinto (1975), were more likely to complete their higher education. 
Finally, the variable "TipoResidência" presented a positive coefficient at the significance level of $5 \%$. It can be concluded, therefore, that the students of the sample who did not live in their own residence at the time of the application for the entrance examination had a chance factor of dropout equals to 2.7181 times the chance factor of the students who lived in their own home. This variable represents a proxy for family income. It can be argued, then, that students from a wealthier family (who live in their own homes) are less likely to dropout accounting programs than their peers from lower-income families. This result is in line with Tinto's (1975) idea that students from families of a higher social class have a cost-benefit relationship with continuing their studies better than lower-income students, the first group is more likely to complete graduation (GISI, 2006; BAGGI \& LOPES, 2011).

After the estimation of the model of dropout prediction, the adjustment capacity of the model was calculated in the Stata12 software by means of classification and influence matrix analysis. Thus, as shown in Table 2, of a total of 63 analyzed subjects who dropped out, the model was able to correctly predict 31 of them. Nevertheless, out of a total of 159 analyzed undergraduate students, the estimated model was able to correctly predict 140 . It is also worth noting that 32 analyzed subjects being considered as graduates were in fact students who dropped out from the program and 19 analyzed subjects being considered dropouts were in fact graduates.

TABLE 2. Classification Matrix of the Estimated Model

\begin{tabular}{l|c|c|c}
\hline Classification & Dropouts (Sample) & Graduates (Sample) & Total \\
\hline Dropouts (Model) & 31 & 19 & 50 \\
\hline Graduates (Model) & 32 & 140 & 172 \\
\hline Total & 63 & 159 & 222 \\
\hline
\end{tabular}

Therefore, as it can be seen from Table 3, the estimated model correctly classifies $77.03 \%$ of the analyzed subjects from the "training" sub-sample. Regarding classificatory power for students who dropped out (sensitivity), the model of dropout prediction is correct in $49.21 \%$ of the cases. Regarding the classification power for students who completed the Accounting Studies program of the UFMG (specificity), the model is correct in $88.05 \%$ of the cases. 
TABLE 3. Classificatory Accuracy of the Estimated Model

\begin{tabular}{l|c|c}
\hline Classificatory Accuracy & Calculus & Percentage \\
\hline Sensitivity & $31 / 63$ & $49,21 \%$ \\
Specificity & $140 / 159$ & $88,05 \%$ \\
Dropout Prediction Value & $31 / 50$ & $63,00 \%$ \\
Graduate Prediction Value & $140 / 172$ & $81,40 \%$ \\
Dropout Misclassification & $32 / 63$ & $50,79 \%$ \\
Graduate Misclassification & $19 / 159$ & $11,95 \%$ \\
Dropout Misclassification by the Model & $19 / 50$ & $38,00 \%$ \\
Graduate Misclassification by the Model & $32 / 172$ & $18,60 \%$ \\
\hline General Classificatory Accuracy & $(31+140) / 222$ & $77,03 \%$ \\
\hline
\end{tabular}

Although the classification accuracy related to the sensitivity was $49.21 \%$, it is important to emphasize that the process leading to dropout is related to several social and economic and demographic variables and, therefore, it may be of great value to use a model which can with eight explanatory variables accurately predict about $50 \%$ of the students that will dropout from the undergraduate program.

Analyzing the Stata12 software results, the area under the ROC (Receiver Operating Characteristic) curve of the estimated model was equal to 0.8050 , signaling a good discrimination (FÁVERO, BELFIORE, SILVA, \& CHAN, 2009). The Hosmer-Leme show test was also estimated and its result did not allow rejection of the null hypothesis that there is no difference between the results predicted by the model and those analyzed in the sample.

\subsubsection{VALIDATION OF THE ESTIMATED MODEL}

To validate the predictive capacity of the estimated model, the "validation" sub-sample was composed of $40 \%$ of the total sample, according to the methodology proposed by Hair Júnior, Black, Babin and Anderson (1998). Thus, the coefficients found in the estimations of the model of dropout prediction (presented in Table 1) related to the analyzed subjects of the "validation" subsample were applied. A cutoff point of values above 0.5 was selected for purposes of classification of dropout. Table 4 presents the result of this validation procedure. 
Table 4. Classification Matrix of the Estimated Model for the "Validation" Subsample

\begin{tabular}{l|c|c|c}
\hline Classification & Dropout (Sample) & Graduate (Sample) & Total \\
\hline Dropout (Model) & 19 & 11 & 30 \\
\hline Graduate (Model) & 24 & 95 & 119 \\
\hline Total & 43 & 106 & 149 \\
\hline
\end{tabular}

It is possible to notice that the model of dropout prediction, estimated from the "validation" subsample, maintained the classificatory accuracy obtained when estimating the "training" subsample. Both sensitivity and specificity show patterns similar to those presented in Table 3.

\subsection{ANALYSIS OF THE QUALITATIVE STAGE}

\subsubsection{FIRST MACRO-CONTEXT: PERIOD BEFORE APPLICATION}

Regarding the moment of the choice of the program, only the interviewee $\mathrm{P}$, the only one to enter higher education directly after finishing high school, stated that she received vocational guidance in the last year of high school: "We performed the [vocational] test and had psychological follow-up during the whole third year of high school." The others stated that they had searched for information about the accounting studies program at UFMG and about the accounting profession from other sources, such as the HEI website, online vocational guidance, professions fair carried out by the UFMG, and through contacts with professionals already graduated. Interviewee I, for example, said: "The person who most influenced me to take the Accounting program instead of Economics, as I wanted initially, was the manager of the printing company I worked for. She was an Accounting graduate and was very satisfied and fulfilled with the program." Similarly, N stated that she worked "in a drugstore in the countryside and the owner of the drugstore was an accountant and she influenced her". It can be said, therefore, that, before beginning an under-graduate program, the interviewees had, in a general way, satisfactory knowledge about the Accounting Studies Program and about the professional performance of the accountant.

Despite this apparent vocation for the profession, the path to accounting has permeated other areas according to some interviewees. The dropoutE, for example, declared that he was a graduate and master in Physics when he decided to apply for the entrance exam prior to acceptance in the Accounting Studies Program of the UFMG. He 
worked as a professor at a private HEI in the capital of Minas Gerais and was dissatisfied with the labor market in the area. He then decided to change his profession. In his words: "Accounting and Computer Sciences were the professions that had more positions available in the public system (...) such as the vacancy for Federal Police expert". The interviewee $M$ reported that when he started the Accounting program at the UFMG in the second half of 2007, he was already a student of Economics at the Pontifical Catholic University of Minas Gerais (PUC-MG) since 2006, before that, he had tried the Medical School for three years. Similarly, the interviewee N stated that he had enrolled in the Accounting Studies Program at the UFMG after his fifth attempt. However, according to the interviewee: "Before, I was applying to another area, I was applying to Medical School."

Another interesting fact concerns the professions of the interviewees' parents. None of them claimed to have a father and/or a mother graduated in Accounting. In addition, all stated that parents did not influence much in their professional choices. In the words of the dropout N: "They have always supported me. The choice was mine. (...)They gave their opinion but without much influence." A similar speech could be identified in the words of the individual M: "They were never for or against. (...)It was my decision after all". And also in the speeches of the interviewee Q: "My family was very quiet, they did not get involved (...) they just said, 'Do what you think you have to do, something that has to do with you.' "“

The 5 interviewees showed great expectations regarding the Accounting Studies Program, and especially about the UFMG. In the words of I: "In 2008, I enrolled the UFMG and was dazzled (...) I had great expectations about the UFMG, the undergraduate program itself, my colleagues and the professors." For the dropout N, the expectation formulated in the period before the beginning of the under-graduate accounting studies program related to his financial situation: "I had great expectation because, at the time, I could not afford any other program in a private university". For this interviewee, therefore, attending a program at a public HEI represented, at the time of the application for the entrance exam, the only way to obtain a higher education diploma.

Finally, as already pointed out in some of the statements of the interviewees, with the exception of $\mathrm{P}$, all of them declared to have work experience previous to the enrollment in the Accounting Studies Program. M, who studied Economics, at the time he was admitted for the Accounting Studies Program at the UFMG, was a trainee in a capital market company. The interviewee E, as already mentioned, worked as 
a professor in a private HEI. The dropout I worked for a print shop when he was accepted by the UFMG selection process. The interviewee $\mathrm{N}$ mentioned having worked as the cashier in a drugstore in the period prior to joining the Accounting Studies Program at the UFMG.

\subsubsection{SECOND MACRO-CONTEXT: POST-ADMISSION PERIOD}

At the beginning of the UFMG Accounting Studies Program, a speech common to most of the interviewees was the frustration of expectations regarding the courses offered by the program. Interviewee $\mathrm{P}$, who had high expectations regarding the courses, said: "The moment I got in was very complicated because it was a huge disappointment (...) we saw the basics first. There was no course directly related to Accounting." Similarly, N emphasized that in the first semester of the program the introductory courses were ministered in the Philosophy and Human Sciences Department (FAFICH). Thus, according to him: "We had no contact with Accounting (...) nor even contact with other students of the Accounting program".

For I, the dissatisfaction was with the quantitative courses: "In the first semester, I already started to have some problems due to a calculation course that was (...) very difficult to me". In the view of this interviewee, the difficulty faced was due to the precarious basic mathematic lessons taken during high school years: "I came from a very poor public school, I had this problem because my basic mathematics skills were terrible (...) I realized that I had a greater difficulty." In addition, the curriculum of the program has a large number of courses in the quantitative area which may not be so useful for the accounting profession: "We take two courses of deep statistics in the program to be doing something entirely different after graduating, like taking tax guide for instance (...) okay, maybe one (...) and the professor of those courses charges you at a level of demand of an Economics professor." It is clear that, in his view (I), the performance of the accounting professional, unlike professionals from other areas, such as Economics, for example, would not require deep knowledge of quantitative methods.

Still regarding the educational curriculum, with the exception of one interviewee $(\mathrm{M})$, who did not notice the impact of the changes in the course grid, all the interviewees described their views on the curricular changes introduced in the grid in the first semester of 2009. The interviewee $\mathrm{N}$ stated that he participated in the team that helped the reformulation of the curriculum of the Accounting Studies Program of the UFMG. According to him: "The changes in the grid placed 
Introduction to Accounting at the beginning of the course (...) we gave this suggestion and the teachers agreed. I think this was a gain because a lot of people wanted to have that contact right from the start." Another interviewee (E) expressed his favorable position, especially regarding the courses of the quantitative area added to the program with the advent of the new educational curriculum: "It is a tool that solves various issues in several areas (...) in the financial area there are several of those issues (...) by the way, the UFMG has a profile that is geared towards research (...) one must be aware of the profile of the university. What does the UFMG do? It produces articles. It fosters research.”

With a negative view of the curricular changes, the interviewee P considered this change to be one of the main factors that contributed significantly to the dropout. In P's words, "There were some courses that I had already taken (...) but as the class load was shorter (...) I had to take them again, because the new courses shared some subjects, others didn't". She also stated that not everything that was taught was necessary for the accounting work: "There were a lot of unnecessary courses (...) they could easily summarize three of them in one (...) that made us waste time". In addition, for her, a program formed by courses more focused on the accounting practice could be more effective.

This dissatisfaction with the curricular structure of the program reduces the student's identification with the institution. According to Tinto's model (1975), the lack of normative congruence of the student's program/institution can cause the students to review their goal of graduation, increasing the propensity to dropout.

Regarding the contact and identification with the faculty, a determinant factor for the students' stay according to Spady (1970) and Tinto (1975), some interviewees expressed their discontent and even regret about the behavior of some professors. The dropout I, for example, said that some professors were presumptuous and unfair. According to this interviewee, one of the professors of the Accounting Studies Program at UFMG told him: "You study at a public university, (...) if you have to work to support your home and because of that you do not have time to study and learn the lessons, feel free to give up the program and give your place to someone who will be able to study here." Still talking about this situation, this interviewee (I) made the following comment: "Being a professor at UFMG makes him arrogant [cause he knows his position is untouchable] (...) I think that if he were working for a [private] university where a statement like that could put his job at stake, he would not make such a comment". 
Very similar speech was reported by the interviewee Q: "I left when I heard from a professor: 'Look, you are taking the place of someone who could be here every day. As you are never here to attend my classes, you should leave."' In addition, she reported another situation in which she also noticed an act of injustice perpetrated by a faculty member of the program. When facing some personal problems, the interviewee said to have warned all the professors of the courses she was enrolled in that she could not attend all their classes. So, according to her, if a professor could not accept that amount of absence throughout the semester, she had decided to drop out of their course. However in her testimony, she said that all professors had told her they understood her motives and assured that they would not fail her due to that amount of absence if she could get enough passing grades. In this context, the interviewee $\mathrm{P}$ explains the moment in which she identified an act of unfairness from one of her professors: "I managed to have the grades to pass, even losing the credits given to students due to their presence and participation in class(...)There were some students who attended classes every day and could not get those grades (...), and then he said to me, 'No, I do not remember having that talk to you, I will fail you due to your amount of absence."

Still regarding the feeling of injustice, the interviewee $\mathrm{N}$ affirmed that a dispute between the professors of the Department of Accounting Studies ended up disturbing his academic life as a student. In his words: "I had a personal issue with two professors (...) I was being tutored by a professor who is not even in the department anymore (...), however his internal issues bore down on me (...)because members of the faculty were having a feud, I was hindered". For the dropout $\mathrm{N}$, the injury was felt when he presented health problems and had to skip several classes. According to the interviewee, professors who had a quarrel with his research tutor were extremely intolerant about his absence, and eventually failed him due to lack of frequency.

Regarding the contact with the other students of the Accounting Studies Program, a necessary condition for the sense of belonging (SPADY, 1970; TINTO, 1975), all the interviewees affirmed that they felt integrated as of the initial terms of the program. The dropout E, who entered the Accounting Studies Program having the higher age among the 5 interviewees, cited a small disagreement with some classmates. In spite of this, in the words of the interviewee himself: "My relationship with the other students, including these, was very good (...) I had no relationship issue with any student. I had a good friendship group there." Also, for the interviewee P, the relationship 
with the other students of the program was always good, even after her decision to drop out. According to the interviewee, when she decided to dropout, her classmates tried to persuade her to continue attending classes. In her words: "My classmates said: 'No, do not leave. We help you. We find a way.'(...) thank God I had a very nice group (...) I missed them when I went back to the program (...) I was not with the same group (...) I did not feel the same integration with the other groups."

It was also possible to observe that the 5 interviewees performed some paid activity while attending the undergraduate program. For all of them, the fact of having been performing activities competing with the Accounting Studies Program was decisive for the occurrence of avoidance. As evidenced by the literature on the subject (SPADY, 1970, 1971; TINTO, 1975; BEAN, 1980), activities parallel to undergraduate studies can reduce student involvement with the university context, thereby reducing commitment to HEI. This result is also in line with the findings of the quantitative step that indicated (through the variable "Idade") that an involvement with the labor market increases the chance of avoidance.

\subsubsection{THIRD MACRO-CONTEXT: POST-DROPOUT PERIOD}

The 5 interviewees were satisfied with the course of their lives after leaving the Accounting Sciences Program of the UFMG. In addition, all have shown interest or are working in areas related to the accounting profession. Interviewee I, for example, pointed out that the salary he currently receives is compatible with his wishes and current needs. In addition, in the company where he currently works there are good growth opportunities, even with the Marketing Diploma (obtained after dropout). When asked about the academic plans for the future and if there is still room for the completion of the Accounting program, interviewee I stated: "I intend to do a graduate course just to be able to compete for a management position (...) and have a very considerable salary increase. After that, I may have the time to dedicate myself to completing the undergraduate course in Accounting."

The interviewee $\mathrm{M}$, after leaving the course of Accounting Studies, finished Economics at PUC-MG and worked for some months as an auditor in an external audit firm. Currently, he is finishing his master's degree in Economics at the UFRGS and working as a consultant, where, according to him, Accounting is well present. In his words, "The company I work in is an IBM's partner, (...) we implement software.(...)The projects I have taken so far are of financial consolidation (...) it's pure Accounting." As it can be seen, 
although the dropouts put aside the Accounting Studies Program of the UFMG, it was not possible to affirm that the vocation had a significant impact on the avoidance of these individuals, according to results presented by Bardagi (2007).

When asked if any action could have been taken by the Accounting Department or by UFMG itself in order to avoid the dropout, some of the interviewees highlighted the lack of preparation of the department in relation to students who were significantly impacted by changes in the curriculum of 2009. For the dropout N: "The area of Accounting Sciences changes all the time (...) the change was not the University's fault. This happened to all universities. But UFMG did not think about the situation of the students who were falling behind."

The interviewee P emphasized the lack of flexibility on the part of the professors regarding the absences and delays. For her, "People who study at night, not only in the Accounting program(...) are people who need to work during the day (...)It is very difficult to reconcile academic life with work life (...) they could be more malleable with the frequency matter." The interviewee I expressed a similar opinion to the interviewee's speech P. For him: "Most professors give a lot of importance to filling the attendance sheet and the matter of attendance is a complicated thing for those who work (...) there is a lack of understanding, especially considering that it is a nightshift course and some people like me need to work." Thus, once again, the duality between work and study has made it clear that in many cases the impossibility of reconciling the two functions may lead the student to opt for professional life rather than academic activities. This result is also in line with the models of Spady (1970) and Tinto (1975).

\section{FINAL CONSIDERATIONS}

The purpose of this article was to identify explanatory factors for the avoidance of the Accounting Studies Program of a Brazilian public university. To do so, a model of dropout prediction was elaborated based on eight socioeconomic and demographic variables, and five semi-structured interviews with dropouts were carried out. The research database was formed by the analysis of 371 students who entered the Accounting Studies Program of the UFMG between 2004/ $1^{\text {st }}$ and $2009 / 1^{\text {st }}$, of which 106 dropped out and 265 completed the program in the analyzed institution. From the procedures performed, it becomes possible to identify some important points in the phenomenon of dropout. 
The estimated model in the quantitative stage showed that the student with the highest probability of avoidance of the Accounting Studies Program of the HEI analyzed is male, who entered the course at the age of 19 years old or more, that the father has at least a complete higher education, who studied most of the high school in the day shift, who did not attend a prep course for taking the entrance exam, who can read in at least one foreign language, born in Belo Horizonte and not living in his own residence. According to the discussion presented in the chapter of analysis of results, the findings of the research corroborate, in parts, with the findings in the literature. Of the eight variables analyzed, four presented a different result than expected. It is believed that the results contrary to the literature show a specific condition of the analyzed sample. Mostly, the cases of dropout from the analyzed sample were voluntary rather than forced, under which the literature presents a greater focus. In general, the quantitative step shows two important points in relation to the dropout phenomenon. First, a gap between the end of high school and the application to the Accounting Studies Program generates a greater propensity to dropout. This result probably reflects the insertion of the student in the job market, which impacts on their involvement with the course, when the undergraduate program begins. In addition, the quantitative stage made it clear that students with great potential (those who entered the program without a prep course for taking the entrance examination, who read in at least one foreign language and whose parents had higher schooling) are more likely to drop out of Accounting in the HEI analyzed. Most likely, this result indicates a lack of identification of these individuals with the course structure, generating an alert so that the institution and the faculty council can think about the process of training of their professionals.

The qualitative step also made clear that the task of reconciling academic and professional activities can contribute to the avoidance of students of the Accounting Studies Program. Having activities competing with the studies may cause some students who have specific socioeconomic conditions to prioritize professional activities over academics. These groups include those with financial and family responsibilities that cannot be postponed. Another important factor identified through the interviews was the contribution of the lack of identification with the faculty in the decision to drop out the program. The literature of the area itself considers that the integration with the faculty plays a large role for the student to feel belonged to the academic milieu. Some excerpts from the interviews showed that lack 
of flexibility of some professors towards the situations experienced by the students, especially those who studied and worked at the same time, were decisive factors for the dropout.

Based on the results produced by this research, it is believed that it is possible to draw up policies to improve the indicators of avoidance and graduation of the Accounting Studies Program of the HEI analyzed and other institutions that present similar conditions. By identifying factors that contribute to what the dropout process happens, it becomes possible to think of mechanisms that aim to avoid reversible dropouts. In addition, the research evidences a gap in higher education regarding the condition of working students. Even though night education has been thought of as a strategy for university expansion, reaching out to people not covered by daytime higher education, there is still no institutionalized policy that considers the needs of students who study and work at the same time.

Finally, it is necessary to point out that the present study presents some limitations, under which it is necessary to interpret the results achieved. The first one refers to the fact that information regarding a single HEI was used. Different institutions may present other factors that impact on the students' dropout of their Accounting Studies Program. In addition, the quantitative step uses data referring to a specific time period (cross section). The socioeconomic characteristics presented by the students at a certain moment of life were not necessarily maintained during the program. The qualitative step also presents as a limitation the small range in relation to the target population of the study. For future research, it is suggested that samples made by different HEIs (public and private) should be used. In addition, it becomes important that new researches focusing on the individuals who study and work at the same time are performed.

\section{ACKNOWLEDGMENTS}

We appreciate the financianal support of CNPq.

\section{REFERENCES}

BAGGI, C. A. S. \& LOPES, D. A. L. Evasão e avaliação institucional no ensino superior: uma discussão bibliográfica. Avaliação, 16(2), p. 355-374, 2011.

BARDAGI, M. P. Evasão e comportamento vocacional de universitários: estudo sobre desenvolvimento de carreira na graduação. 242 p. Tese (Doutorado em Psicologia). 
Programa de Pós-Graduação em Psicologia da Universidade Federal do Rio Grande do Sul. Porto Alegre, 2007.

BARDAGI, M. P. \& HUTZ, C. S. Evasão universitária e serviço de apoio ao estudante: uma breve revisão da literatura brasileira. Psicologia Revista, 14(2), p. 279-301, 2005.

BARDAGI, M. P. \& HUTZ, C. S “Não havia outra saída”: percepções de estudantes evadidos sobre o abandono do curso superior. Psico- USF, 14(1), p. 95-105, 2009.

BARDAGI, M. P.; LASSANCE, M. C. P.; PARADISO, A. C.; MENEZES, I. A. Escolha profissional e inserção no mercado de trabalho: percepções de estudantes formados. Psicologia Escolar e Educacional, 10(1), p. 69-82, 2006.

BEAN, J. P. Dropout and turnover: The synthesis and test of a causal model of student attrition. Research in Higher Education,12, p. 155-187, 1980.

BRAGA, M. M.; PEIXOTO, M. C. \& BOGUTCHI, T. F. A evasão no ensino superior brasileiro: o caso da UFMG. Avaliação, 8(3), p. 161-189, 2003.

CUNHA, J. V. A.; DE LUCA, M. M. M.; SAMPAIO, G. A.; CORNACCHIONE JR., E. B.; OTT, E. Who is being left behind? A decade of dropout in Brazilian undergraduate programs of business administration and accounting. Revista de Educação e Pesquisa em Contabilidade, 9(2), p. 120-136, 2015.

DURSO, S. O.; CUNHA, J. V. A.; NEVES, P. A. \& TEIXEIRA, J. D. V. Fatores motivacionais para o mestrado acadêmico: uma comparação entre os discentes de ciências contábeis e ciências econômicas à luz da teoria da determinação. Revista Contabilidade \& Finanças, 27(71), p. 243-258, 2016.

FÁVERO, L. P.; BELFIORE, P.; SILVA, F. L. \& CHAN, B. L. Análise de dados: modelagem multivariada para tomada de decisões. Rio de Janeiro: Elsevier, 2009.

FERREIRA, L. R. C. \& MARTINO, M. M. F. Padrão de sono e sonolência do trabalhador estudante de enfermagem. Revista da Escola de Enfermagem da USP, 46(5), p. 11781183, 2012.

FURTADO, V. V. A. \& ALVES, T. W. Fatores determinantes da evasão universitária: uma análise com alunos da UNISINOS. Contextus, 10(2), p. 115-129, 2012.

GISI, M. L. Educação superior no Brasil e o caráter de desigualdade do acesso e da permanência. Revista Diálogo Educacional, 6(17), 97-112, 2006.

HAIR JUNIOR, J. F.; BLACK, W. C., BABIN, B. J. \& ANDERSON, R. E. Multivariate data analysis. $7^{\mathrm{a}}$ ed. New Jersey: Prentice-Hal, 20091.

LASSIBILLE, G. \& GÓMEZ, L. N. Why do higher education students drop out? Evidence from Spain. Education Economics, 16(1), p. 89-105, 2008.

LOUREIRO, L. M. J. \& GAMEIRO, M. G. H. Interpretação crítica dos resultados estatísticos para lá da significância estatística. Revista de Enfermagem Referência, 3(3), p. 151-162, 2011. 
LOWE, J. \& GAYLE, V. Exploring the work/life/study balance: the experience of higher education students in a Scottish further education college. Journal of Further and Higher Education, 31(3), p. 225-238, 2007.

MATOS, R. S. \& MACHADO, A. F. Diferencial de rendimentos por cor e sexo no Brasil (1987-2001). Econômica, 8(1), 5-27, 2006.

NES, L. S.; EVANS, D. R. \& SEGERSTROM, S. C. Optimism and college retention: mediation by motivation performance, and adjustment. Journal of Applied Social Psychology, 39(8), p. 1887-1912, 2009.

ORTIZ, E. A. \& DEHON, C. Roads to success in the Belgian French community's higher education system: predictors of dropout and degree completion at the Université Libre de Bruxelles. Research in Higher Education, 54(6), p. 693-723, 2013.

PEREIRA, E.; BERNARDO, M. P. S. L.; D’ALMEIDA, V. \& LOUZADA, F. M. Sono, trabalho e estudo: duração do sono em estudantes trabalhadores e não trabalhadores. Cadernos de Saúde Pública, 27(5), 975-984. DOI: 10.1590/S0102-311X2011000500015, 2011.

REIS, M. C. \& RAMOS, L. Escolaridade dos pais, desempenho no mercado de trabalho e desigualdade de rendimentos. Revista Brasileira de Economia, 65(2), p. 177-205, 2011.

REISEL, L. \& BREKKE, I. Minority dropout in higher education: a comparison of the United States and Norway using competing risk event history analysis. European Sociological Review, 26(6), p. 691-712, 2010.

SANTOS, D. F.; SOBRAL, F. S.; CORREA, M. D.; ANTONOVZ, T. \& SANTOS, R. F. Perfil do profissional contábil: estudo comparativo entre as exigências do mercado de trabalho e a formação oferecida pelas instituições de ensino superior de Curitiba. Revista Contemporânea de Contabilidade, 8(16), p. 137-152, 2011.

SCHULTZ, T. (1988). Education investment and returns. In: CHENEY, H.; SRINIVASAM, T.(ed.). Handbook of Development Economics. North-Holland, Amsterdam; Capítulo 13; p. 543-630, 1988.

SILVA, G. P. Análise da evasão no ensino superior: uma proposta de diagnóstico de seus determinantes. Avaliação (UNICAMP), 18(2), p. 311-333, 2013.

SILVA, R. Deserción: competitividad ó gestión? Revista Lasallista de Investigación, 2(2), p. 64-69, 2005.

SMITH, M. Research methods in accounting. London: SAGE Publications, 2003.

SPADY, W. G. Dropouts from higher education: an interdisciplinary review and synthesis. Interchange, 1(1), 64-85, 1970.

SPADY, W. G. Dropouts from higher education: toward an empirical model. Interchange, 2(3), p. 38-62, 1971

STRAHAM, S. \& CREDÉ, M. Satisfaction with college: re-examining its structure and its relationships with the intent to remain in college and academic performance. Journal of College Student Retention: Research, Theory \& Practice, 16(4), p.537-561, 2015. 
TAMER, C. M. V. S.; VIANA, C. C.; SOARES, L. A. C. F. \& LIMA, M. S. Perfil do profissional contábil demandado pelo mercado de trabalho: um estudo no norte do Brasil. Revista Universo Contábil, 9(3), p. 143-162, 2013.

TINTO, V. Dropout from higher education: a theoretical synthesis of recent research. Review of Educational Research, 45(1), p. 89-125, 1975.

WALMSLEY, A.; WILSON, T. \& MORGAN, C. Influences on a College Student's Major: A Developmental Perspective. Journal for the Liberal Arts and Sciences, 14(2), p. 25-46, 2010.

WALSH, K. J. \&KURPIUS, S. E. R. Parental, residential, and self-belief factors influencing academic persistence decisions of college freshmen. Journal of College Student Retention: Research, Theory \& Practice, 18(1), p. 49-67, 2016.

\section{NOTES}

Submission: $08 / 10 / 2017$

Approvation: 12/01/2018

Contact:

Rua Maestro Cardim, 1170, Bela Vista São Paulo|São Paulo|Brazil

CEP 01.323-001

${ }^{1}$ Note: This article respected the ethical procedures related to research on human subjects and was approved by the Research Ethics Committee of the Federal University of Minas Gerais (CAAE No. 31175214.9.0000.5149). 